\title{
Pneumatosis Cystoides Intestinalis Induced by the Alpha-glucosidase Inhibitor Miglitol
}

\author{
Kuniyuki Kojima ${ }^{1}$, Tatsuhiro Tsujimoto ${ }^{2,3}$, Hisao Fujii ${ }^{2}$, Tomoko Morimoto ${ }^{1}$, \\ Seisaku Yoshioka ${ }^{1}$, Saki Kato ${ }^{1}$, Yumi Yasuhara ${ }^{1}$, Shigeyuki Aizawa ${ }^{1}$, Mizuho Sawai ${ }^{1}$, \\ Shiro Makutani ${ }^{4}$, Koji Yamamoto ${ }^{1}$, Tadao Mochi ${ }^{1}$ and Hiroshi Fukui ${ }^{3}$
}

\begin{abstract}
Pneumatosis cystoides intestinalis (PCI) is a rare condition in which pneumocysts develop in the submucosa or subserosa of the colon. We report herein a case of PCI induced by the alpha-glucosidase inhibitor ( $\alpha \mathrm{GI})$ miglitol. There have been 9 recorded cases of PCI induced by other $\alpha$ GIs, but this is the first report of miglitol causing PCI. The PCI lesions in our case were smaller than those induced by voglibose or acarbose. The possibility of PCI should be considered in diabetic patients on $\alpha$ GI therapy who complain of gastrointestinal symptoms, and the gastrointestinal tract should be thoroughly investigated in these patients.
\end{abstract}

Key words: pneumatosis cystoides intestinalis, alpha-glucosidase inhibitor, miglitol, colonoscopy, diabetes mellitus

(Inter Med 49: 1545-1548, 2010)

(DOI: 10.2169/internalmedicine.49.3634)

\section{Introduction}

Pneumatosis cystoides intestinalis (PCI) is a rare condition in which multiple pneumocysts develop in the submucosa or subserosa of the colon (1). The etiological mechanisms are unclear although a mechanical theory, a chemical theory, a bacterial theory, and a counter-perfusion supersaturation theory have been proposed. In recent years, cases of PCI induced by alpha-glucosidase inhibitors ( $\alpha \mathrm{GIs})$, a new class of antidiabetic agents, have been reported. Our PubMed search yielded only 9 cases of PCI associated with $\alpha$ GI therapy (2-10). Of the different $\alpha$ GIs, reports of PCI induced by voglibose and acarbose have been published, but this is the first report of miglitol causing PCI. In this case report, we present a case of PCI probably induced by miglitol, along with a review of the literature.

\section{Case Report}

A 58-year-old man started receiving $150 \mathrm{mg}$ per day of miglitol (an $\alpha \mathrm{GI}$ ) in June 2008 for the treatment of type 2 diabetes mellitus. He did not receive any medicine other than miglitol. Plain abdominal radiography before miglitol therapy did not reveal gas collection along the wall of the colon or free air. His subsequent glycemic control was good. There was nothing particular in his medical history except for diabetes mellitus. His family history was not remarkable. He was admitted into our hospital for investigation and treatment of lower abdominal pain, and rectal bleeding in February 2009.

Laboratory investigations revealed no abnormalities in the white blood cell count (WBC: $8,000 / \mu \mathrm{L}$ ), red blood cell count (RBC: $\left.410 \times 10^{4} / \mu \mathrm{L}\right)$, hemoglobin $(\mathrm{Hb}: 14.9 \mathrm{~g} / \mathrm{dL})$, hemoglobinA1c (HbA1c: 5.4\%), and carcinoembryonic antigen (CEA: $5.0 \mathrm{ng} / \mathrm{mL}$ ), but the C-reactive protein (CRP) was slightly elevated $(0.45 \mathrm{mg} / \mathrm{dL})$. Abdominal computed to-

\footnotetext{
${ }^{1}$ Department of Internal Medicine, Hattori Memorial Hospital, Nara, ${ }^{2}$ Department of Endoscopy and Ultrasound, Nara Medical University, Kashihara, ${ }^{3}$ The Third Department of Internal Medicine, Nara Medical University, Kashihara and ${ }^{4}$ Department of Radiology, Hattori Memorial Hospital, Nara

Received for publication March 8, 2010; Accepted for publication April 19, 2010

Correspondence to Dr. Tatsuhiro Tsujimoto, tat-tyan@xa2.so-net.ne.jp
} 

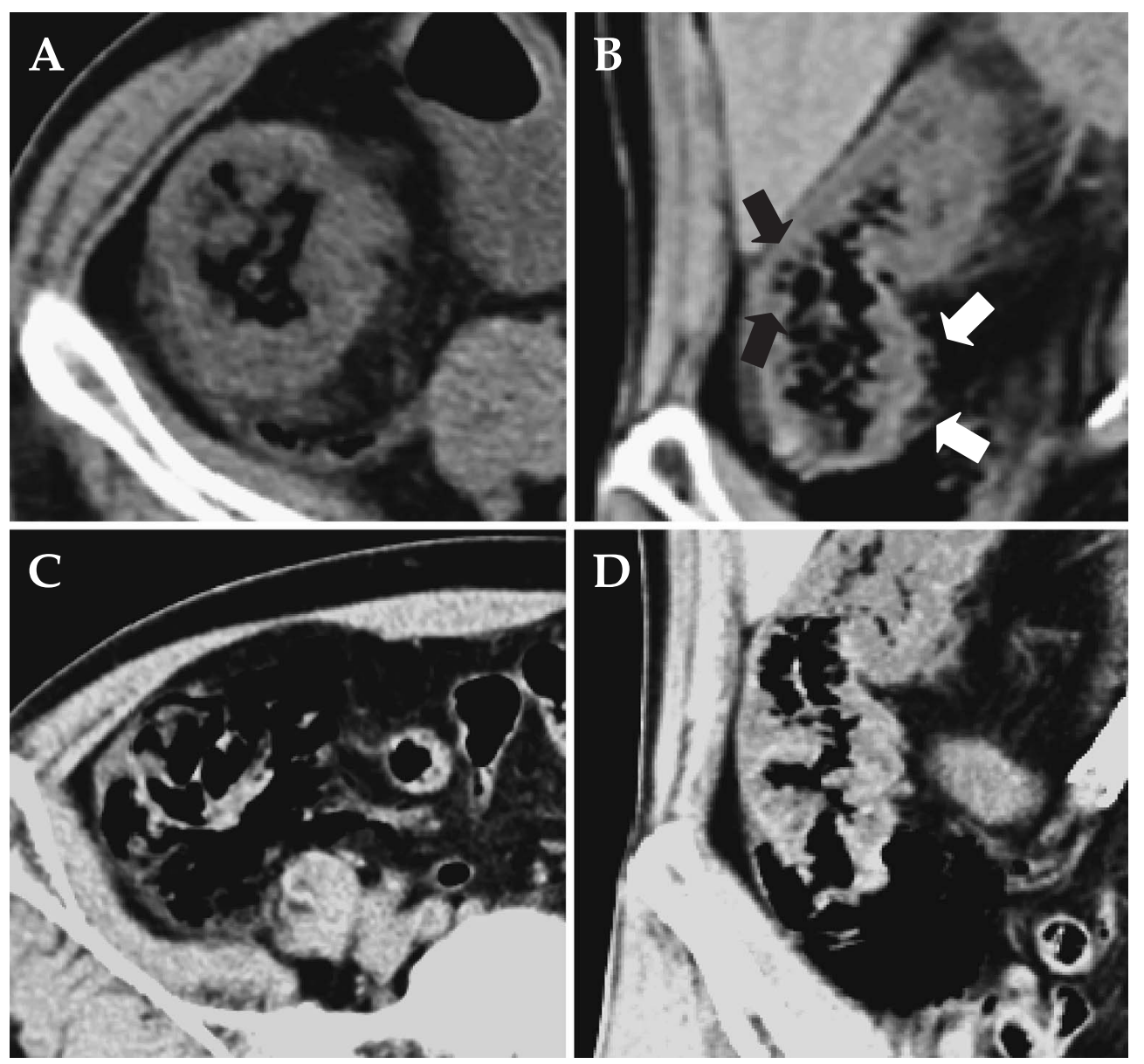

Figure 1. Abdominal computed tomography (CT) scans on admission. A: Horizontal scan. Thickening of the walls is noticed in the ileocecal region and ascending colon, and cloudiness of the adjacent adipose tissue is seen. B: Vertical scan. Submucosal (black arrows) and subserosal (white arrows) gases are seen in the bowel wall. C: Horizontal scan. Extramural gases are seen in the mesenteries and retroperitoneal cavity. D: Vertical scan. Extramural gases are seen in the mesenteries and retroperitoneal cavity.

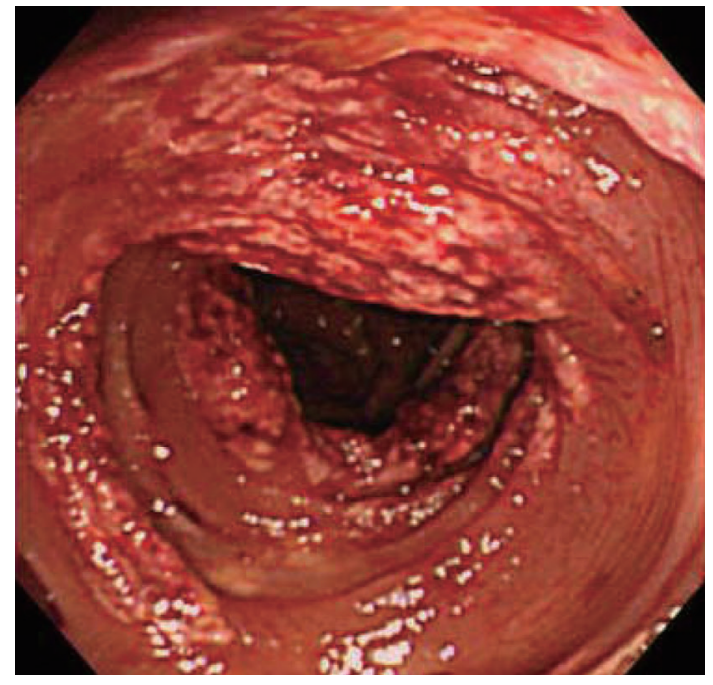

Figure 2. Colonoscopy on admission revealed multiple smaIl projections associated with erythema and erosions in the ileocoecal region and ascending colon. coecal region and ascending colon, as well as submucosal and subserosal gas. Extramural gas also was seen in the mesenteries and retroperitoneal cavity (Fig. 1). Colonoscopic examination revealed multiple small projections associated with erythema and erosions in the ileocoecal region and ascending colon (Fig. 2). The histopathological examination demonstrated multiple small pneumocysts within the submucosa (Fig. 3). Bowel perforation was considered unlikely on the basis of the patient's stable condition, the lack of signs of peritonism, and the weak evidence of inflammation, and the diagnosis of PCI was made on the basis of the aforementioned findings. Miglitol was suspected as the cause of this patient's PCI. Management was therefore conservative, comprising cessation of miglitol, fasting, and fluid supplementation. The patient progressed well, and was discharged 12 days after repeat colonoscopy confirmed the disappearance of pneumocysts in the ileocoecal region and ascending colon (Fig. 4). 


\section{Discussion}

PCI is a rare condition in which submucosal or subserosal pneumocysts develop in the submucosa or subserosa of the colon. The etiological mechanisms are unclear, although PCI reportedly develops in association with raised intra-intestinal pressure due to ileus (11), surgery (12), colonoscopy (13), respiratory conditions such as chronic bronchitis and emphysema (14), trichloroethylene exposure (15), connective tissue diseases (16), immunosuppressant therapy (1), ingestion of carbohydrates such as lactulose (17) and sorbitol (18), and counter-perfusion super-saturation (19).

A few reports have been recently published on PCI associated with $\alpha$ GI therapy. The mechanism is thought to in-

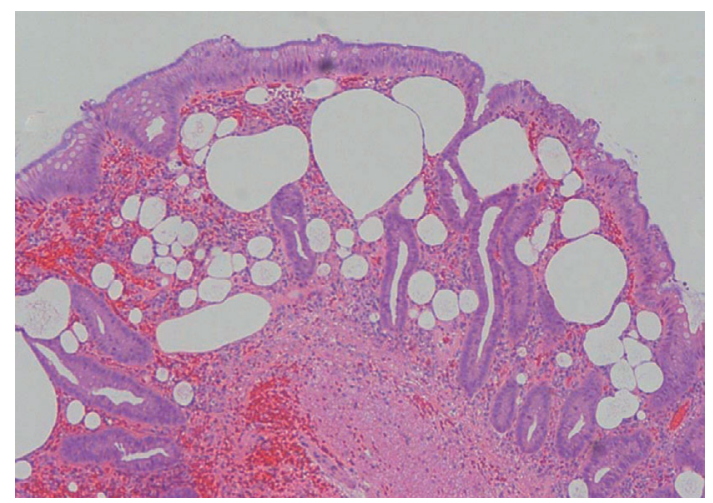

Figure 3. Histopathological examination of the colonic mucosa, using Hematoxylin and Eosin stain, revealed multiple pneumocysts within the submucosa of the colon $(\times 100)$. volve intestinal gas production through fermentation by the intestinal flora of carbohydrates, of which absorption is inhibited by $\alpha$ GI. This factor, along with peristaltic hypofunction associated with diabetic autonomic neuropathy, leads to raised intraluminal pressure, allowing the gas-producing bacteria to invade the colonic mucosa through mucosal breaks, forming pneumocysts (3).

Our review of the medical literature in PubMed between 1983 and 2009 yielded 9 case reports of PCI associated with $\alpha$ GI therapy (2-10). We highlighted the details of these cases, totaling 10 in addition to the present case, in Table 1,

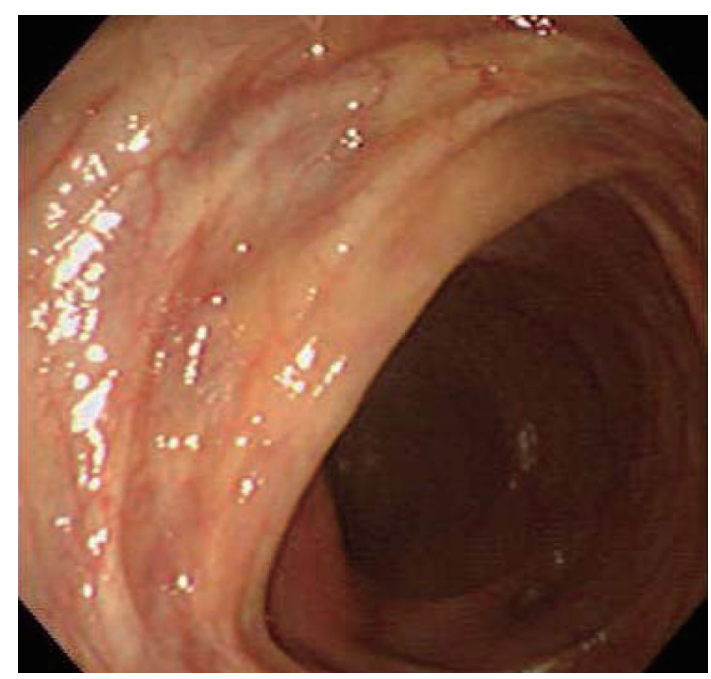

Figure 4. Colonoscopy on discharge revealed disappearance of the pneumocysts with erythema and erosion in the ileocoecal region and ascending colon.

Table 1. A Summary of Previously Reported Cases of Pneumatosis Cystoides Intestinalis (PCI) after Alpha-Glucosidase Inhibitor $(\alpha \mathbf{G I})$ Treatment for Diabetes Mellitus

\begin{tabular}{|c|c|c|c|c|c|c|c|c|c|}
\hline No. & Author & $\begin{array}{l}\text { Age } \\
\text { Sex }\end{array}$ & Chief complaint & $\begin{array}{c}\text { The } \alpha \text { GI agent } \\
\text { Quantity of } \alpha \mathrm{GI} \\
\text { Duration }\end{array}$ & $\begin{array}{l}\text { Disease other than } \\
\text { diabetes mellitus }\end{array}$ & $\begin{array}{c}\text { Concomitant } \\
\text { drug }\end{array}$ & Localization & $\begin{array}{l}\text { Prescription of } \alpha \mathrm{GI} \\
\text { after PCI onset }\end{array}$ & $\begin{array}{c}\text { Treatment } \\
\text { Outcome } \\
\text { Duration to outcome }\end{array}$ \\
\hline 1 & Hayakawa et al. (2) & $\begin{array}{c}64 \\
\text { F }\end{array}$ & Abdominal distention & $\begin{array}{c}\text { Voglibose } \\
0.6 \mathrm{mg} / \text { day } \\
1 \mathrm{month}\end{array}$ & Unknown & Insulin & $\begin{array}{l}\text { Ascending colon, } \\
\text { Transverse colon }\end{array}$ & Discontinuation & $\begin{array}{c}\text { Conservative treatment } \\
\text { Healing } \\
4 \text { days }\end{array}$ \\
\hline 2 & Azami (3) & $\begin{array}{l}87 \\
F\end{array}$ & $\begin{array}{c}\text { Abdominal distention, } \\
\text { Anorexia }\end{array}$ & $\begin{array}{c}\text { Acarbose } \\
150 \mathrm{mg} / \text { day } \\
1 \text { year }\end{array}$ & Hypothyroidism & SU & Small intestine & Discontinuation & $\begin{array}{c}\text { Conservative treatment } \\
\text { Healing } \\
5 \text { days }\end{array}$ \\
\hline 3 & Yanaru et al. (4) & $\begin{array}{l}61 \\
M\end{array}$ & $\begin{array}{l}\text { Abdominal distention, } \\
\text { Constipation, } \\
\text { Hematochezia }\end{array}$ & $\begin{array}{l}\text { Voglibose } \\
0.6 \mathrm{mg} / \mathrm{day} \\
5 \text { years }\end{array}$ & Unknown & SU & Sigmoid colon & Discontinuation & $\begin{array}{c}\text { Conservative treatment } \\
\text { Healing } \\
28 \text { days }\end{array}$ \\
\hline 4 & Hisamoto et al. (5) & $\begin{array}{l}56 \\
\mathrm{~F}\end{array}$ & No abdominal symptoms & $\begin{array}{c}\text { Voglibose } \\
0.6 \mathrm{mg} / \text { day } \\
7 \text { days }\end{array}$ & Interstitial pneumonia & Steroid & Ascending colon & Discontinuation & $\begin{array}{c}\text { Conservative treatment } \\
\text { Healing } \\
7 \text { days }\end{array}$ \\
\hline 5 & Furio et al. (6) & 64 & $\begin{array}{c}\text { Abdominal pain, } \\
\text { Diarrhea, Tenesmus, } \\
\text { Weight loss }\end{array}$ & $\begin{array}{l}\text { Acarbose } \\
\text { unknown } \\
3 \text { years }\end{array}$ & Unknown & Insulin & $\begin{array}{l}\text { Caecum, Ascending colon, } \\
\text { Trasverse colon, } \\
\text { Sigmoid colon }\end{array}$ & Discontinuation & $\begin{array}{c}\text { Conservative treatment } \\
\text { Healing } \\
15 \text { days }\end{array}$ \\
\hline 6 & Maeda et al. (7) & $\begin{array}{l}72 \\
F\end{array}$ & Rt lower abdominal pain & $\begin{array}{l}\text { Voglibose } \\
0.9 \mathrm{mg} / \mathrm{day} \\
3 \text { years }\end{array}$ & Minimal change disease & $\begin{array}{c}\text { Insulin } \\
\text { Steroid } \\
\text { Immunosupressant }\end{array}$ & Unknown & Discontinuation & $\begin{array}{c}\text { Conservative treatment } \\
\text { Healing } \\
7 \text { days }\end{array}$ \\
\hline 8 & Tsujimoto et al. (9) & $\begin{array}{l}69 \\
\text { M }\end{array}$ & $\begin{array}{l}\text { Abdominal distention, } \\
\text { Hematochezia }\end{array}$ & $\begin{array}{c}\text { Voglibose } \\
0.6 \mathrm{mg} / \text { day } \\
1 \text { year } 8 \text { months }\end{array}$ & Myasthenia gravis & $\begin{array}{c}\text { SU } \\
\text { Steroid }\end{array}$ & Sigmoid colon & Discontinuation & $\begin{array}{c}\text { Conservative treatment } \\
\text { Healing } \\
14 \text { days }\end{array}$ \\
\hline 9 & Vogel et al. (10) & 65 & Lt abdominal pain & $\begin{array}{c}\text { Acarbose } \\
150 \mathrm{mg} / \text { day } \\
12 \text { years }\end{array}$ & Hypertention & Nothing & Ascending colon & Discontinuation & $\begin{array}{c}\text { Conservative treatment } \\
\text { Healing } \\
7 \text { days }\end{array}$ \\
\hline 10 & Our case & $\begin{array}{l}58 \\
M\end{array}$ & $\begin{array}{l}\text { Lower abdominal pain, } \\
\text { Hematochezia }\end{array}$ & $\begin{array}{l}\text { Miglitol } \\
150 \mathrm{mg} / \text { day } \\
8 \text { months }\end{array}$ & Nothing & Nothing & $\begin{array}{c}\text { Caecum, } \\
\text { Ascending colon }\end{array}$ & Discontinuation & $\begin{array}{c}\text { Conservative treatment } \\
\text { Healing } \\
12 \text { days }\end{array}$ \\
\hline
\end{tabular}


and include a review of the literature. The patients' ages ranged from 53 to 87 (mean: 64.9) years. The male to female ratio was 3 to 7 . The causative agent was voglibose in 6 cases, acarbose in 3, with the present case being the first to be caused by miglitol. The interval between commencement of $\alpha$ GI therapy and the onset of PCI varied greatly (from 7 days to 11 years). The presenting symptom was abdominal fullness in 4 cases $(40 \%)$ and rectal bleeding in 3 (30\%), neither of which is specific for PCI (Table 1). The most commonly affected site was the ascending colon in 6 cases $(60 \%)$, followed by the sigmoid colon in $3(30 \%)$.

Various radiological modalities are useful in the diagnosis of PCI. In an earlier case report and literature review, we analyzed the radiological findings of the previously reported cases (9). Plain abdominal radiography demonstrated linear radiolucent gas collections along the bowel wall in most cases, and abdominal CT scanning demonstrated pneumatosis within or along the bowel wall. Subserous pneumocysts in particular are liable to rupture, exhibiting intraperitoneal free gas, making it important to distinguish this condition from bowel perforation. The colonoscopic findings include multiple smooth-surfaced hemispherical submucosal tumorlike protrusions, similar in color to the mucosa and resembling cystic lesions. In the present case, however, the mucosal surfaces of the lesions were reddish, and the projec- tions were smaller than those induced by voglibose or acarbose. The histopathological findings of the multiple small pneumocysts also differed from those in previous case reports.

Once the diagnosis of PCI is made, conservative management is the general rule. Stopping $\alpha$ GI therapy is important, with all reported cases resolving within 28 days of cessation. In our case, miglitol was suspected as the causative factor for PCI, and consequently miglitol was ceased and recovery was confirmed 12 days later with conservative measures comprising fasting and fluid supplementation.

Having experienced a case of PCI thought to be caused by miglitol, we conducted a search of the literature. Although few cases of $\alpha \mathrm{GI}$-associated PCI have been recently reported, this is the first report of miglitol causing PCI. The pneumocysts in this case were smaller than those caused by voglibose and acarbose. This may be characteristic for miglitol, as it is absorbed in the small intestine (20). Endoscopic findings of miglitol-induced PCI will become clear with the increase of the reports in the future. The possibility of PCI should be considered in diabetic patients on $\alpha \mathrm{GI}$ therapy with gastrointestinal symptoms, and the gastrointestinal tract should be thoroughly investigated in these patients.

\section{References}

1. Heng Y, Schuffler MD, Haggitt RC, Rohrmann CA. Pneumatosis intestinalis: a review. Am J Gastroenterol 90: 1747-1758, 1995.

2. Hayakawa T, Yoneshima M, Abe T, Nomura G. Pneumatosis cystoides intestinalis after treatment with an $\alpha$-glucosidase inhibitor. Diabetes Care 22: 366-367, 1999.

3. Azami Y. Paralytic ileus accompanied by pneumatosis cystoides intestinalis after acarbose treatment in an elderly diabetic patient with a history of heavy intake of maltitol. Intern Med 39: 826829, 2000.

4. Yanaru R, Hizawa K, Nakamura S, et al. Regression of pneumatosis cystoides intestinalis after discontinuing of alpha-glucosidase inhibitor administration. J Clin Gastroenterol 35: 204-205, 2002.

5. Hisamoto A, Mizushima T, Sato K, et al. Pneumatosis cystoides intestinalis after $\alpha$-glucosidase inhibitor treatment in a patient with interstitial pneumonitis. Intern Med 45: 73-76, 2006.

6. Furio L, Vergura M, Russo A, et al. Pneumatosis coli induced by acarbose administration for diabetes mellitus. Case report and literature review. Minerva Gastroenterol Dietol 52: 339-346, 2006.

7. Maeda Y, Inaba N, Aoyagi M, Kanda E, Shiigai T. Fulminant pneumatosis intestinalis in a patient with diabetes mellitus and minimal change nephrotic syndrome. Intern Med 46: 41-44, 2007.

8. Saito M, Tanikawa A, Nakasute K, Tanaka M, Nishikawa T. Additive contribution of multiple factors in the development of pneumatosis intestinalis: a case report and review of the literature. Clin Rheumatol 26: 601-603, 2007.

9. Tsujimoto T, Shioyama E, Moriya K, et al. Pneumatosis cystoides intestinalis following alpha-glucosidase inhibitor treatment: a case report and review of the literature. World J Gastroenterol 14: 6087-6092, 2008.

10. Vogel Y, Buchner NJ, Szpakowski M, Tannapfel A, Henning BF. Pneumatosis cystoides intestinalis of the ascending colon related to acarbose treatment: a case report. J Med Case Reports 3: 9216,
2009.

11. Gruenberg JC, Grodsinsky C, Ponka JL. Pneumatosis intestinalis: a clinical classification. Dis Colon Rectum 22: 5-9, 1979.

12. Horiuchi A, Akamatsu T, Mukawa K, Ochi Y, Arakura N, Kiyosawa K. Case report: Pneumatosis cystoides intestinalis associated with post-surgical bowel anastomosis: a report of three cases and review of the Japanese literature. J Gastroenterol Hepatol 13: 534537, 1998.

13. McCollister DL, Hammerman HJ. Air, air, everywhere: pneumatosis cystoides coli after colonoscopy. Gastrointest Endosc 36: 7576, 1990.

14. Keyting WS, McCarver RR, Kovarik JL, Daywitt AL. Pneumatosis intestinalis: a new concept. Radiology 76: 733-741, 1961.

15. Yamaguchi K, Shirai T, Shimakura K, et al. Pneumatosis cystoides intestinalis and trichloroethylene exposure. Am J Gastroenterol 80: 753-757, 1985.

16. Quiroz ES, Flannery MT, Martinez EJ, Warner EA. Pneumatosis cystoides intestinalis in progressive systemic sclerosis: a case report and literature review. Am J Med Sci 310: 252-255, 1995.

17. Goodman RA, Riley TR 3rd. Lactulose-induced pneumatosis intestinalis and pneumoperitoneum. Dig Dis Sci 46: 2549-2553, 2001.

18. Duncan B, Barton LL, Eicher ML, Chmielarczyk VT, Erdman SH, Hulett RL. Medication-induced pneumatosis intestinalis. Pediatrics 99: 633-636, 1997.

19. Florin TH, Hills BA. Does counterperfusion supersaturation cause gas cysts in pneumatosis cystoides coli, and can breathing heliox reduce them? Lancet 345: 1220-1222, 1995.

20. Sels JP, Huijberts MS, Wolffenbuttel BH. Miglitol, a new alphaglucosidase inhibitor. Expert Opin Pharmacother 1: 149-156, 1999.

(C) 2010 The Japanese Society of Internal Medicine http://www.naika.or.jp/imindex.html 